\title{
INTERCULTURALITY AND GAMIFICATION IN TEACHER TRAINING
}

\author{
INTERCULTURALIDADE E GAMIFICAÇÃO NA FORMAÇÃO DE PROFESSORES
}

\section{INTERCULTURALIDAD Y GAMIFICACIÓN EN LA FORMACIÓN DE PROFESORES}

\author{
Fernando González Alonso ${ }^{1}$
}

\begin{abstract}
The present work refers to gamification in the context of Intercultural Education, as a playful technology that motivates and stimulates students' effort and acuity and, in addition to teamwork, enables students to learn to work in cooperation with others, to achieve the goal with a specific, neuroeducational style, methodology and resources, a science that develops brain functions with certain educational strategies and technologies. Intercultural Education is based on the teaching of values such as communication, solidarity, respect, tolerance and inclusion of diverse students in school and the cultural and social integration of people in a common project. With this look, we present a training process through a learning workshop through gamification techniques such as less escape space and brain, along with inclusive dynamics such as "Visual Intercultural", "Comparing Interculturality with" and "Unboxing Intercultural ", Foster reflection on the conceptual and experiential framework regarding interculturality, migration and its challenges, impacts and processes with factors considered 'for' and 'against', close to education and their relationship with interculturality.
\end{abstract}

KEYWORDS: Intercultural Education. Gamification. Teaching and Learning.

\section{RESUMO}

O presente trabalho faz referência à gamificação no contexto da Educação Intercultural, como uma tecnologia lúdica que motiva e estimula o esforço e a acuidade dos alunos e, somada ao trabalho em equipe, oportuniza que os alunos aprendam a trabalhar em cooperação com os outros, a fim de atingir a meta com um estilo, metodologia e recursos específicos e baseados na neuroeducação, uma ciência que desenvolve funções cerebrais com certas estratégias e tecnologias educacionais. A Educação Intercultural baseia-se no ensino de valores como comunicação, solidariedade, respeito, tolerância e inclusão de diversos alunos na escola e na integração cultural e social das pessoas em um projeto comum. Com esse olhar, apresentamos um processo de formação através de um workshop de aprendizado por meio de técnicas de gamificação, como menos espaço de escape e cérebro, juntamente com dinâmicas inclusivas como "Visual Intercultural", "Comparando a interculturalidade com" e "Unboxing Intercultural", fomentam a reflexão sobre a estrutura conceitual e experiencial relativa interculturalidade, migração e seus desafios, impactos e processos com os fatores considerados 'a favor' e 'contra', próximos à educação e sua relação com a interculturalidade.

PALAVRAS-CHAVE: Educação Intercultural. Gamificação. Ensino e Aprendizagem.

\footnotetext{
${ }^{1}$ Professor Encargado de Cátedra na Faculdade de Educação da Universidade Pontifícia de Salamanca (UPSA), Salamanca (Espanha).
} 


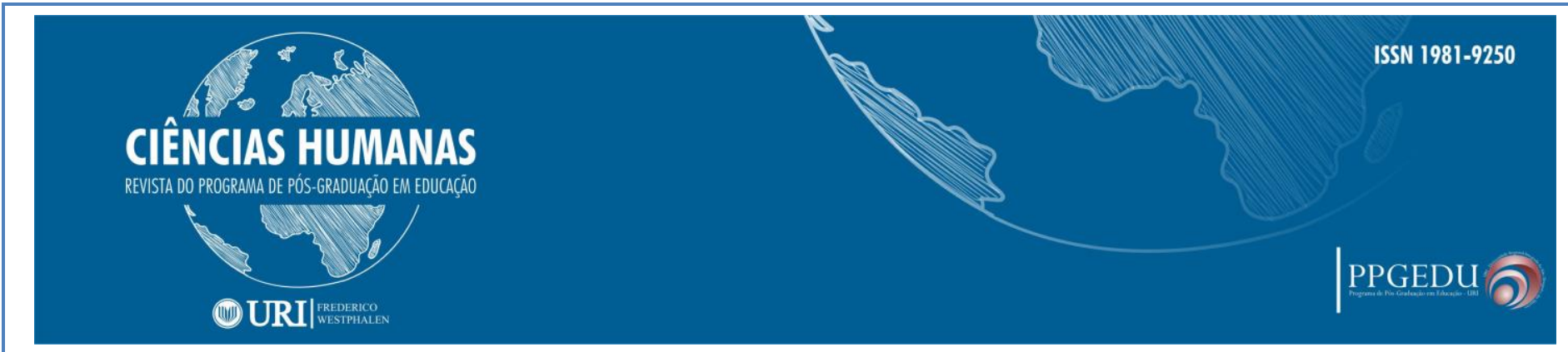

\section{RESUMEN}

El presente trabajo se refiere a la gamificación en el contexto de la Educación Intercultural, como una tecnología lúdica que motiva y estimula el esfuerzo y la agudeza de los estudiantes y, además del trabajo en equipo, permite a los estudiantes aprender a trabajar en cooperación con otros, para lograr el objetivo con un estilo, metodología y recursos neuroeducativos específicos, una ciencia que desarrolla funciones cerebrales con ciertas estrategias y tecnologías educativas. La Educación Intercultural se basa en la enseñanza de valores como la comunicación, la solidaridad, el respeto, la tolerancia y la inclusión de diversos estudiantes en la escuela y la integración cultural y social de las personas en un proyecto común. Con este aspecto, presentamos un proceso de capacitación a través de un taller de aprendizaje a través de técnicas de gamificación como menos espacio de escape y cerebro, junto con dinámicas inclusivas como "Visual Intercultural", "Comparando la interculturalidad con" y "Unboxing Intercultural ", Fomentar la reflexión sobre el marco conceptual y experimental sobre la interculturalidad, la migración y sus desafíos, impactos y procesos con factores considerados 'a favor' y 'en contra', cercanos a la educación y su relación con la interculturalidad.

PALABRAS CLAVE: Educación Intercultural. Gamificación Enseñanza y Aprendizaje.

\section{INTRODUCTION}

Multiculturalism has an important historical journey associated with the development, growth and education of the peoples. In particular, in Montreal (Canada), in the United States during the sixties, and in Europe during the seventies.

The term Intercultural Education originates in the eighties. Before, people used to talk about multicultural, pluricultural, multi-ethnic and multiracial education about assimilationist paradigms or ethnic conciliators, according to the cultural background and the experience of certain attitudes and values in the personal and institutional involvement (GONZÁLEZALONSO; DE CASTRO-HERNÁNDEZ, 2012). It is still stated that

The value of interculturality in schools, as areas of formal education where the educative system is developed, also resides in the ability of the system itself to face cultural and linguistic diversity. It rests as well upon the ability to offer an intercultural education, able to promote integration among all students, and to improve coexistence among the different sectors of the school population (p.190).

Thus, "traditional education turned into an intercultural education based on the exchange, interaction, solidarity and reciprocity among children from different cultures" (PUIG; MORENO, 1991, p. 15).

Interculturality is a value which is present among people, organisms and societies that live a common project on the basis of the dialogue and the interrelation in shared spaces and times. In this context, respect, tolerance, solidarity, equality, adaptation, effort and integration

\begin{tabular}{l|l} 
Recebido em: 10/06/2019 & Aceito em: 16/08/2019
\end{tabular}




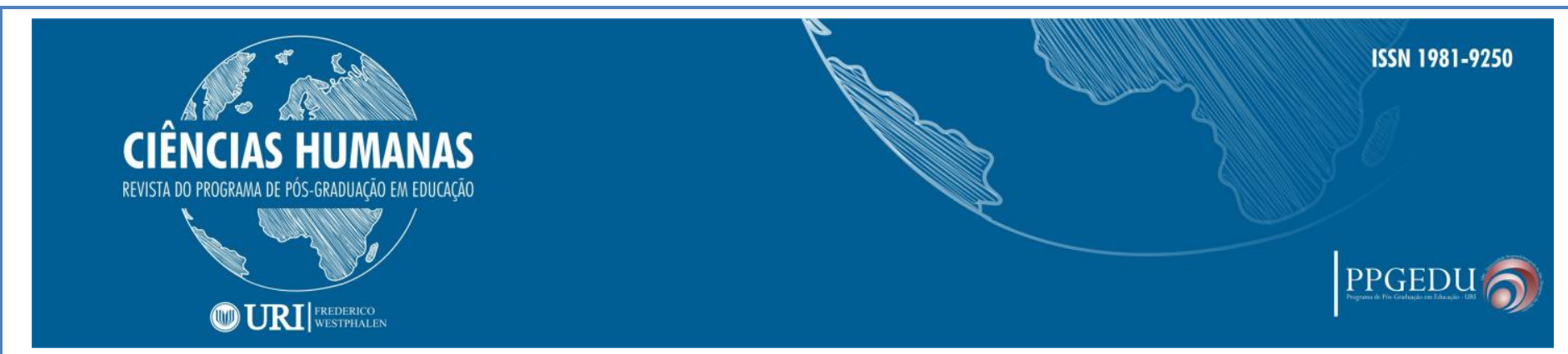

equally arise among all of them. Intercultural Education aims to bring together and train in these interculturality-related values all those who teach and learn in social-educative environments, so that coexistence in those areas and in society is improved every day.

If in this training process, we connect gamification to Intercultural Education, so that it becomes a more playful process, able to motivate, to foster teamwork in a cooperative way, and stimulate the effort and ingenuity of everyone in order to achieve a goal, then, we enhance both concepts with a more enriching approach.

Therefore, I am referring to Intercultural Education and gamification as a learning workshop through gamification techniques such as escape room and brain less. These techniques are based on various dynamics like "Visual Intercultural", "Comparing interculturality to" and "Unboxing Intercultural". Hence, I intend that the groups of participants in the workshop provide their own knowledge and the one acquired from others, as well as the shared reflection.

This way, "Visual Intercultural" tries to explain and disclose the following aspects: the theoretical framework on interculturality, migration and its challenges, education in relation to interculturality, the people and processes that are involved, and the factors perceived as in favour or against the process. This is carried out through a procedure to search materials and resources, using gamification techniques so that the groups could define and explain the words and expressions they are meant to.

With the gamification dynamic of "Comparing interculturality to" other terms that each group has found or has been proposed, an analogous method that fosters the reflection through an analysis between both intercultural terms is followed. The meaningful learning, teamwork, shared reflection, and the comparative synthesis, are some of the characteristics of this intercultural gamification dynamic.

The third abovementioned dynamic uses the opening of an envelope or package beyond surprise and admiration to apply the "Unboxing Intercultural" technique. It consists in opening an envelope or package that contains new terms that will be linked to interculturality, in order to establish "what Interculturality provides" and upon "the interculturality we like”. We will relate what we see and the results of the relationship of these new terms with interculturality. Mowlabocus (2018) ensures that the videos that reveal 


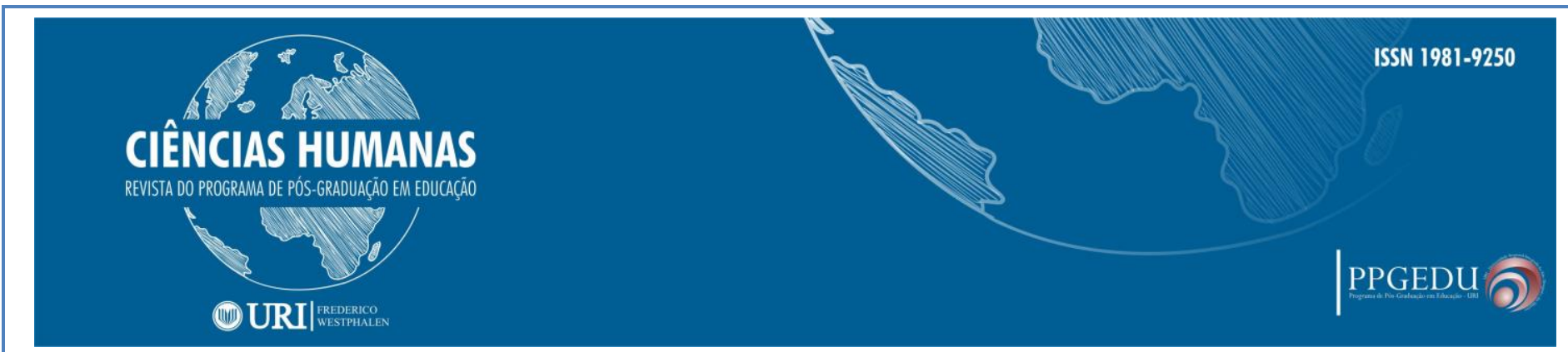

the opening of objects via Youtube have become an important income source, being object of interest by observers and critics, turning, according to Mahuta (2017), into a popular genre that connects friends and partners in an intercultural way, thanks to YouTube.

With all this process, I attempt to perpetuate, from the recreational incorporation of the gamification, its technology and materials, a training path that we all have regarding the Intercultural Education. In order to achieve the foregoing, it is important to share our knowledge and experiences, and to think about the contributions made by the new terms across the words, as well as the gestures and the graphic representation of a visual. It is also relevant to reflect on the explanation we give to the big group about the interrelation between challenges and impacts that migratory and intercultural processes have among the people involved and their educational methods.

\section{INTERCULTURAL EDUCATION AND GAMIFICATION}

According to González-Alonso and De Castro-Hernández (2012), interculturality does not only concern the acceptance of diversity, but it also opts for a symbology and meaning that give sense to the integration and mutual adaptation. Intercultural Education, beyond the historical approaches in the different countries and cultures and beyond the intercultural models, seeks in time and space the knowledge of people, cultures, countries, languages, values and lifestyles. These sought aspects enable to reach the coexistence and integration of foreign students and ethnic minorities both in school and society, as well as to achieve the acceptance and respect for every individual in all its diversity.

Clark \& Dervin (2014) ensure that, thanks to globalisation, the technological process, the migration phenomenon and the mobility, we have reached a changing Intercultural Education. This arouses fast training processes that generate reflection and investigation coherently. Intercultural Education is a clear answer to the educational quality requirements that pretend to comprehend the cultural diversity and the achievement of the new intercultural competencies (BEACCO et al., 2016).

For these reasons, Dervin (2015) expresses that Intercultural Education in general, and the intercultural in particular, are very present at teaching training contexts, even though this 


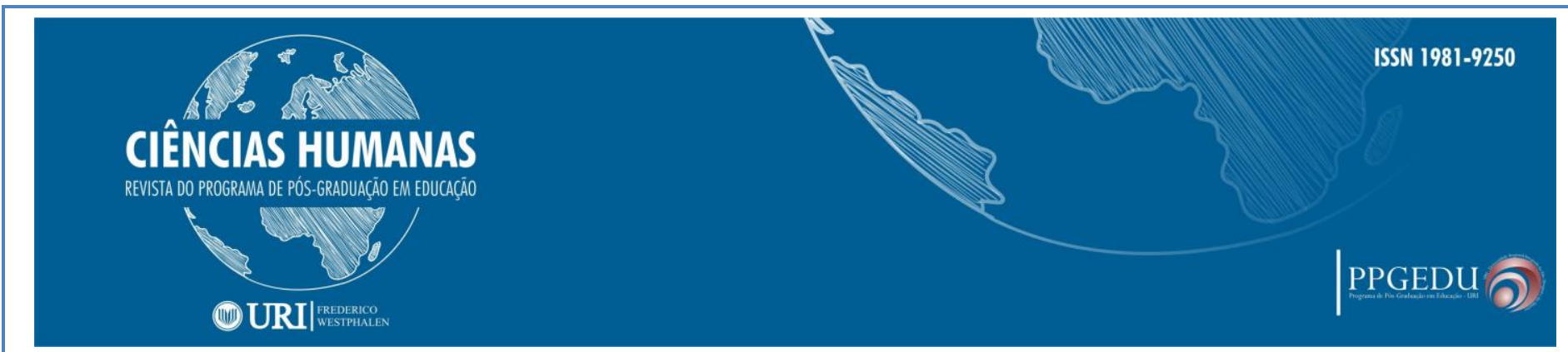

is sometimes carried out covertly in multiculturality, using other concepts and representations.

This occasionally creates controversy about the convenience of a certain model of Intercultural Education at schools and above the theoretical framework that defines it. Such theoretical framework is sometimes far from reality according to Leeman \& Ledoux (2005).

Intercultural Education also implies an attitude of positive appreciation towards people, places, forms, customs and ways of communicating and interacting culturally, for understanding, comprehension and respect to be fundamental active principles (LEIVA OLIVENCIA, 2011). Hence, interculturality as a value and Intercultural Education as a paradigm applied to school education and to society in general terms, have to be always present and not taken for granted nor known or understood beforehand. It is a constant, a continuum.

Nevertheless, what is understood by gamification? What does it contribute to teaching? Does it enrich and reinforce Intercultural Education? I will try to give answer to these questions below.

Gamification comes from the English term gamification, which has to do with the use of the game as main element through its techniques and dynamics for boosting and stimulating participants in creativity, effort, teamwork, productivity, etc. It was first used in 2008 in the business field, being spread later onto other areas such as the educational field, for achieving, in a more serious and playful space in the classroom, the students' motivation and acquisition of certain learning, in a more participative and ludic way. Hence the term gamification. Nicholson (2015) claims that gamification has to do with the use of ludic techniques in specific environments aiming short-term rewards in fields such as business, marketing and corporate management mainly, whilst in educational contexts the tendency is emergent (DICHEVA et al., 2015), and even incipient (Hew, 2016), even though it seems to be booming in primary education (Wiggins, 2016), and not in higher education.

Beyond the use of videogames through the network, gamification in education incorporates the way a game is played and its elements in order to attain certain aspects. These include: concentration, effort and motivation of the members of a classroom team, as well as the personal and public recognition for the acquired achievements, which were reached thanks to everyone's collaboration and cooperation in order to get the prize and the 


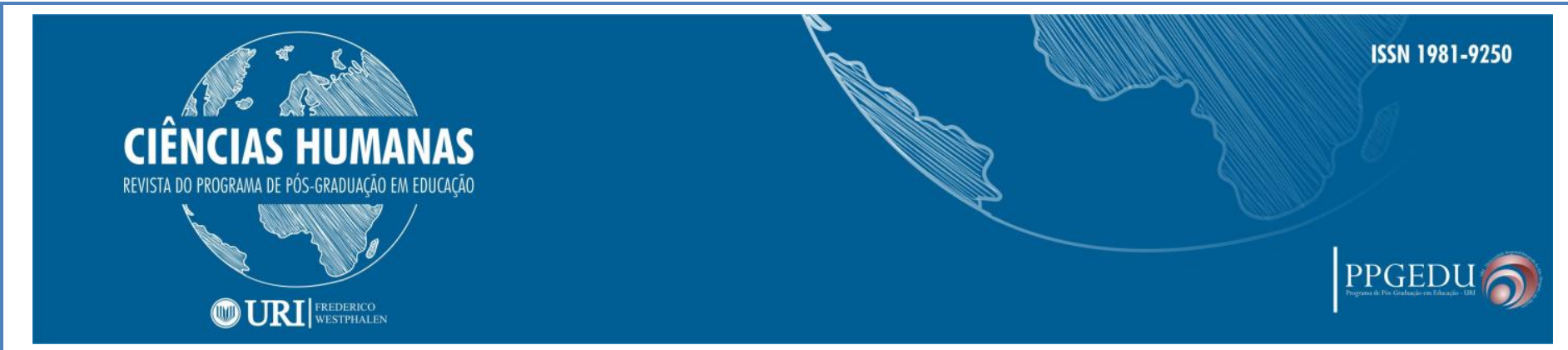

learning. A good gamification in the classroom requires from the appropriate application of techniques and methods, where the game mechanics and dynamics are properly exposed and integrated (URH et alt., 2015).

The university learning spaces also require, according to González González, \& Mora Carreño (2015), from educational experiences based on gamification's principles and mechanisms, on the basis of the theoretical frameworks and the teaching and learning promotion, the resolution of problems linked to specific areas. Intercultural Education as a discipline linked to the different levels of education, is an accurate reference. Likewise, it is applied to the training of future teachers and professors. The theoretical and practical knowledge has to be basic for educators. The crisis of the traditional education at University, in combination with the application of the ICTs knowledge, can boost both students and teachers in teaching and learning.

Even though there is still a lack of studies referred to the gamification techniques and strategies in a systematic way and in the long term (NACKE; DETERDING, 2017), and some others have little theoretical framework (HUANG; HEW, 2018), there are other studies that connect gamification uses and resources to education. For example, the Horizon Report Inform (2013).

FIGURE 1 - Clue and Test fluid. Source: Own elaboration based on Edelvives

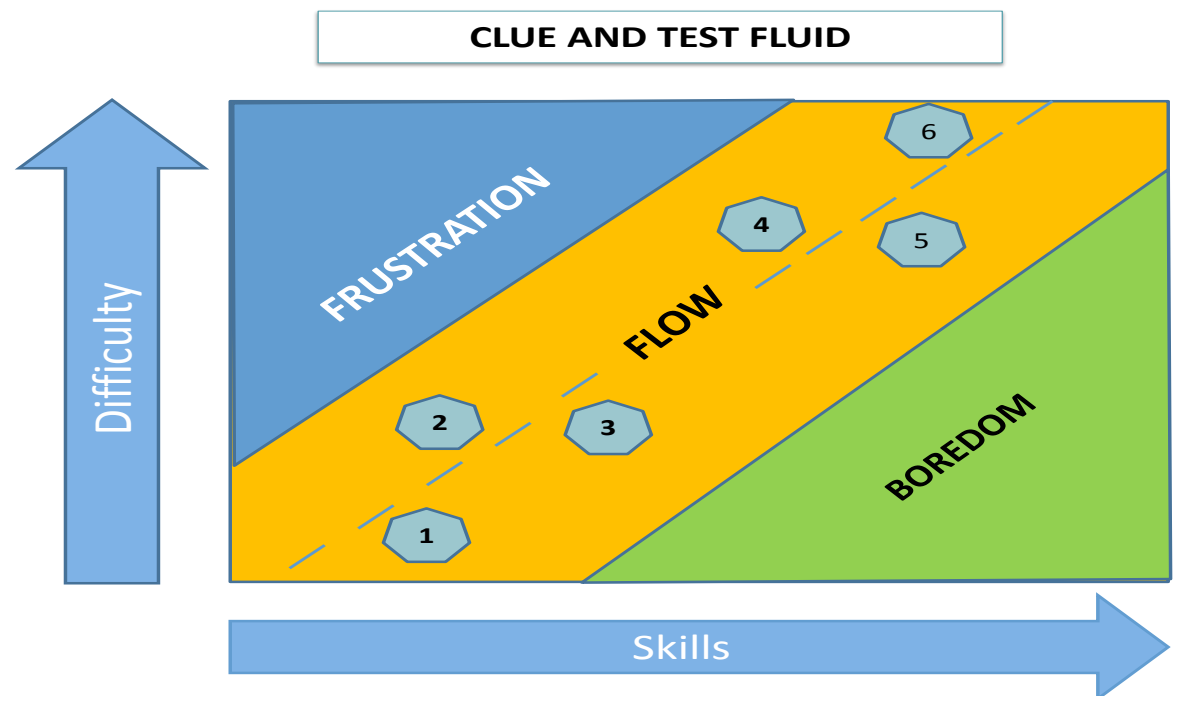

Fonte: https://www.edelvives.com/es/Noticias/d/taller-1-brainlessescape 


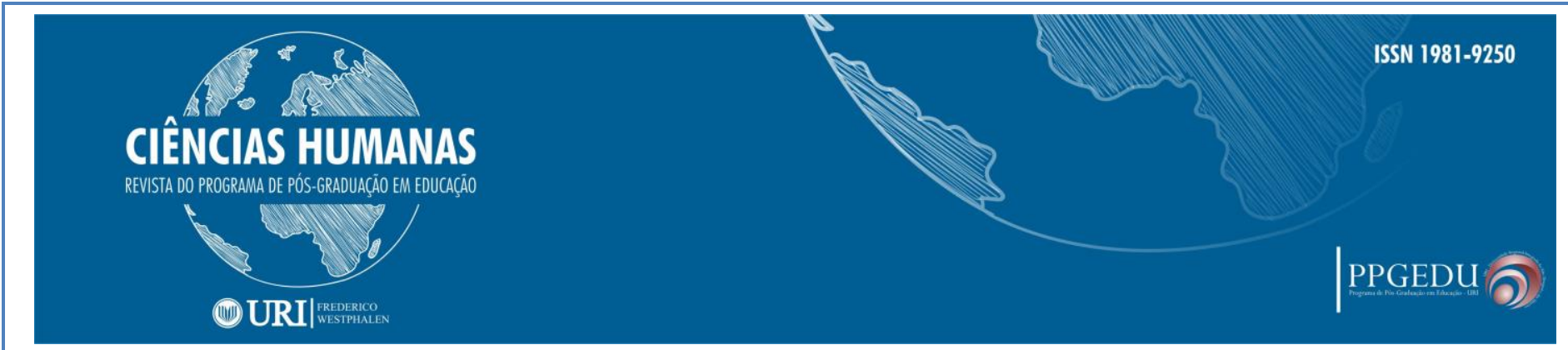

The elements of gamification according to Díaz-Cruzado and Troyano (2013), using the characteristics expressed by Kapp (2012) and which are shared by Zichermann and Cunningham (2011), are based on: a) the basis of the game: possibility of playing to achieve the challenge following certain rules to play and learn; b) the mechanics, badges or rewards that maintain the attention and the self-improvement are granted; c) the aesthetics, the team members perceive stimulating figures; d) the idea of the game is the goal to be achieved by the players, getting abilities by virtually playing real situations; e) the game-player connection includes the game instructions or resources that must be easy so that the player does not quit; f) players, whether they are motivated or not, regardless of profiles; g) the motivation through the tests' fluid level, balancing frustration with boredom thanks to information or motivating badges; h) the learning promotion: giving points or feedback; i) the problem-solving: achieving the goal, the objective, the box, the envelope, reaching the end after having overcome the difficulties.

\section{Escape Room and Brain Less:}

Two significant gamification experiences were "Escape Room" or "Brain Less", or even a combination of both of them.

Escape Room has to do with investigation and team games, which can be developed at any age and where there are no risks against people integrity. The group or groups are meant to exit the room in which they are, solving prepared games with clues that have a guiding thread, exposing the acuity and individual intuition, such as the ingenious and group abilities, in a fight against a fixed period of time (around one hour) in order to escape. The room could be set in a time and place that refers to, for instance, a castle, a museum, a bank, a church, a casino, or even a murderer's house. In any case, players are meant to follow the clues, discovering the riddles and mysteries and escaping the place in time. Nicholson (2015) ensures Escape Room is based on live action teams, with clues and jigsaws to accomplish a goal in a short period of time, and that it has grown in popularity and has overcome the challenges (WIEMKER, ELUMIR; CLARE, 2015). 


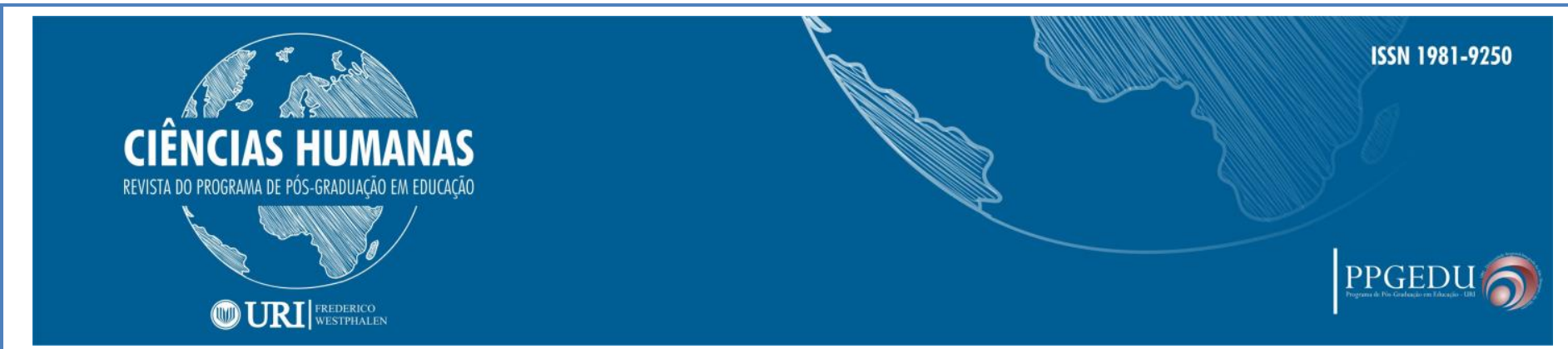

The second one, Brain Less, refers to the brain exercise while trying to solve tests or riddles, to get to the next enigma or attain the final prize in a fight against the time. This is achieved by playing games that can be more or less obvious, intuitive and participatory. These games can take you to intermediary boxes until you can open the final box or envelope, with the desired contents or surprises.

The combination of both would have to do with the performance of the group activities planned to discover mysteries that lead to the final box in order to escape that place in a certain time. In this case, we talk about a "Brain Less - Escape Room" that some institutions such as Edelvives ${ }^{2}$ use in their pursuit to innovate and perform games that can stimulate the brain, being related to neuroscience or neuroeducation. As González-Alonso and De Castro-Hernández (2019) state, we talk about neuroeducation when we take into account the contribution of Pedagogy, Psychology and Neuroscience as the sciences present in teaching, mental cognition and brain operation for the personal development.

To this end, there may be visible materials for the groups, such as: Clues inside a book, alphanumeric codes, pieces of hidden QR codes, secret envelopes, locks of three, four or more numbers, lockable boxes, badges or rewards, etc.

Inside the locked boxes or envelopes, we can find different materials. For example, popular or famous quotes about interculturality, words about interculturality to be defined, positive and negative terms, educational ones or about processes related to interculturality, colour sticks, red cellophane pieces of paper for installing them over a printed decoder, sentences in a mosaic made of spikes, codes for opening boxes or finding envelopes, cards with codes to be solved, numbered brain profiles, hand gestures for elaborating sentences or decoding a number, computer graphics with references, passwords, QR codes with computer graphics, etc.

The steps are adjusted to gamification strategies so students could get involved in the performance of tasks that they already had to do, clarifying the learning objectives as a formative and playful process (MOORE; CAMPBELL, 2019), but now in a more playful

\footnotetext{
${ }^{2}$ Edelvives. Jornadas Educativas 2019. Dale al coco. Available at https://www.edelvives.com/es/jornadaseducativas
} 


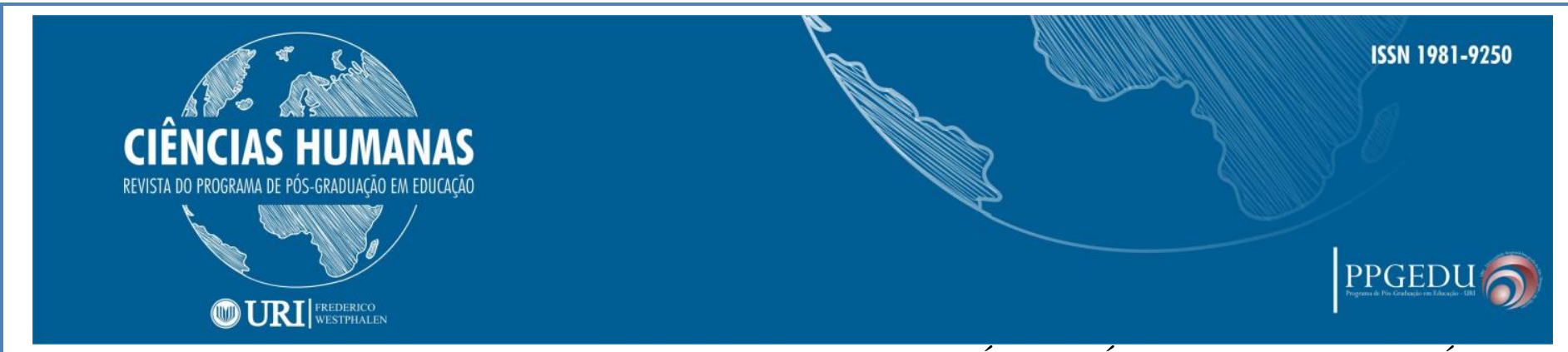

way, in order to achieve the learning and motivation (PÉREZ-LÓPEZ; RIVERA-GARCÍA, 2017).

These steps in the interculturality workshop could be:

1. The selection of the learning objectives:

If it requires previous knowledge, the proposed contents must be assessed, and the expected abilities must be applied and practiced. If it does not require previous

knowledge, the new knowledge, abilities and processes need to be introduced. It is important to foster the critical thinking and teamwork.

2. The knowledge of the working group and its characteristics:

Its age, likes, interests, previous experiences with this kind of activities, etc.

3. The creation of the narrative of the experience:

Selecting the topic: future, fantasy, old Egypt, detectives, laboratories, horror, festivities (Christmas, Easter, summer holidays, Halloween, school parties, family meeting, etc.) and contextualising it within a mission or conflict. Aiming this, one has to solve different challenges to deactivate a bomb, solve a crime, find an important object, remove a computer virus, escape from a prison, find a magic or healing potion, etc.

4. The specification of the rules or guidelines:

A planification and creation period is required, as well as a period for installing it, preparing it, and executing it. It has to be decided whether all players are going to participate at the same time or not, and whether they have a common material for everyone or in duplicate for each different group. One has also to think about the available space, getting adapted to the facilities with a story able to enhances it.

For instance, some of the rules may be: Do not run, do not touch the signals or indicators, do not force the boxes or envelopes to open them, indicate the maximum time (this can be visible in a chronometer, being susceptible to change depending on the group progress), clarify the number of clues and their typology.

5. The selection of the required materials: 


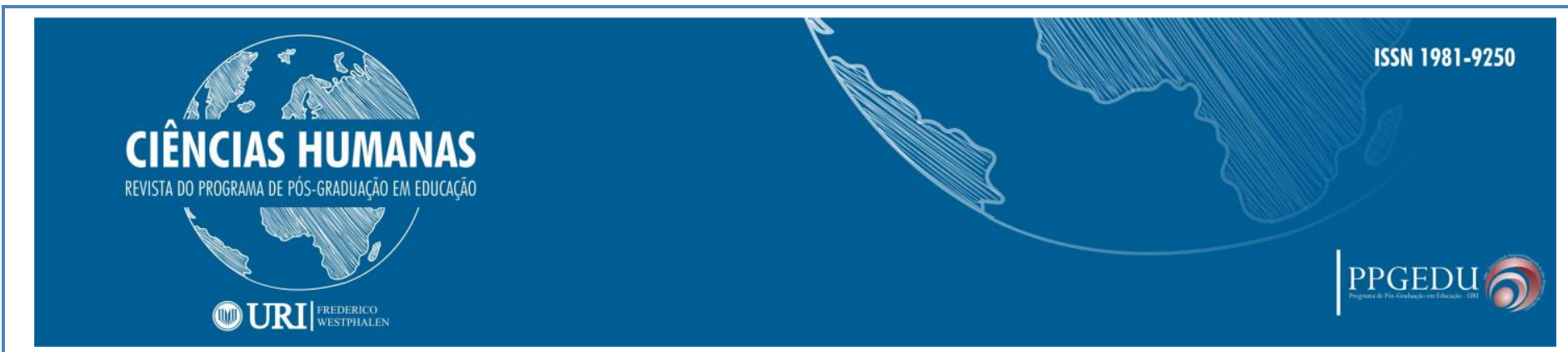

One has to think, decide and elaborate the material and resources required for the story told via the experience (boxes, locks, lanterns, scenery, envelopes, signboards, codes, torches...)

6. The selection and organisation of the challenges, enigmas or mysteries:

It consists in planning the path the group is meant to follow so the process can flow when they feel frustrated because of the difficulties they may experience, or because of boredom due to the lack of practice and certain abilities. Therefore, different paths can be created: a) open or parallel with riddles or guessing games in a horizontal line, leading to the box, envelope or the big challenge; b) consecutive or vertical: bottom-up, the discovering of a first enigma drives to the next one above it, and this continues until reaching the envelope or big challenge; c) multiple paths of riddles in a vertical way, which individually lead to its own big challenge or surprise box, and finally d) hybrid or combined paths, in order to reach the big challenge or envelope, and guessing the tests that drive to different levels.

7. The approach of the final conclusion and reflection: To this effect, we could ask ourselves which would be the final reflection we would like our groups to do at the end of the game.

8. The assessment by groups or as an only big group instead, taking into account if the intended objectives have been achieved, if every group answered to what was expected, if the story was the appropriate guiding thread, or if the rules were precise and complied. Additionally, if the materials were well prepared and worked efficiently, if the enigmas, clues and mysteries followed the right timing, and, finally, if the reflection itself has reunited the expected elements.

\section{INTERCULTURAL EDUCATION WITHIN A GAMIFIED WORKSHOP}

The workshop has been the chosen format to carry out this education with intercultural characteristics. The importance of this workshop relies on the practical attention, the 


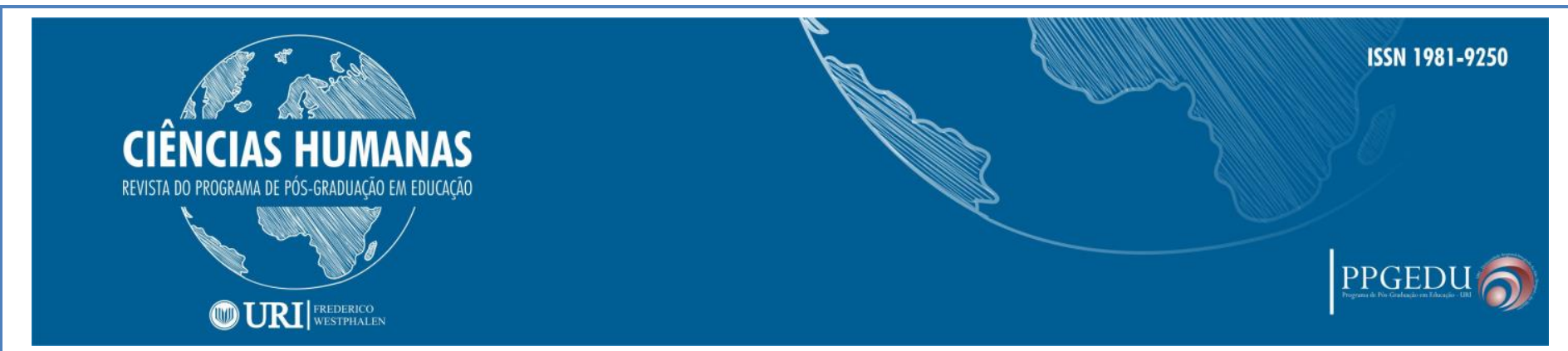

orientation and assessing that the group can be constantly receiving, and on the training offered to participants (Segura, 2004). Likewise, the application strategy of the workshop allows the use of spaces, the solving of conflicts and problems linked to the minor or major cultural population, stakeholder groups, associations of immigrants, etc. (RODRÍGUEZ NAVARRO et al., 2011) and the implementation of intercultural strategies, activities and appropriate materials that respond to the needs and objectives established within the workshop (BUENDIA EISMAN, et al., 2015).

The workshop consists of three gamification experiences: The first one is called "the terms of interculturality", the second one, "comparing interculturality", and, the third one, “intercultural unboxing".

\section{Gamification 1: “Visual Intercultural”}

Reflecting on interculturality and its terms in a cooperative, playful and participative way, on the basis of this first collaborative gamification experience, where the first task is to define terms which are interrelated to interculturality. Later on, they must relate it with the people involved, adding the needed intercultural processes, the education and its elements, and the interrelation with terms which are in favour and against interculturality. The object of this first dynamic is the mental and graphic construction of the idea of the term that has been assigned to the group, as a visual expression that explains it.

\section{a) Defining the terms}

Through the unboxing technique, envelopes are opened to surprisingly discover the terms Interculturality, immigration, impacts/challenges, education and rights.

Objective: Defining and explaining the concept linked to interculturality that has been assigned to the group.

Materials: Envelopes that contain a word or concept related to interculturality or migration. Presentation using Powerpoint or on a paper sheet, explaining the steps to be followed and the criteria to be taken into account.

Procedure: Each group starts looking for their envelope or box, thanks to a certain clue that they acquired as the game progressed. Once all groups have found it, they are required to open the envelopes one by one, indicating the word that has been randomly 


\section{CIÊNCIAS HUMANAS}

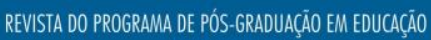

\section{(1) URI|}

selected for them. The groups, one by one, are asked to approach for the first time the meaning of the term out loud. Collaborating all together, the terms that appeared in the game can be interrelated.

The first group that found the envelope or box with the word connected to interculturality or immigration, through the unboxing technique, chooses an envelope. These possible envelopes to be chosen have different captions written on them: "people", "processes", ·education", "positive or in favour" (+), or "negative or against" (-).

Result: The group has been set in a natural way. It has searched its word and given an initial explanation of it. There is no doubt some other words and materials will be needed for explaining each term, whether individually or all together.

\section{b) Terms related to people and interculturality}

Objective: Organising, selecting and negotiating the exchange of words related to people, to prepare the explanation of the term they have been given.

Procedure: The group that has got the envelope or box about people linked to interculturality, will order them on a table or even on the floor. This allows the members of the group and also others to ask for the words they want to include in their speech in order to explain the first term they were given. They will need to use the negotiation technique for exchanging their own words for others, as required. At the end, a member of the group that can be called "emigrant" will explain to the others the speech built thanks to their own words and the exchanged ones via negotiation.

Materials: Envelope which contains the words concerning people (see the following table). These are the words that take part in the interculturality, migration, impacts, challenges, education and rights processes. The list of people's words can be incremented.

TABLE 1 - Terms related to people and interculturality

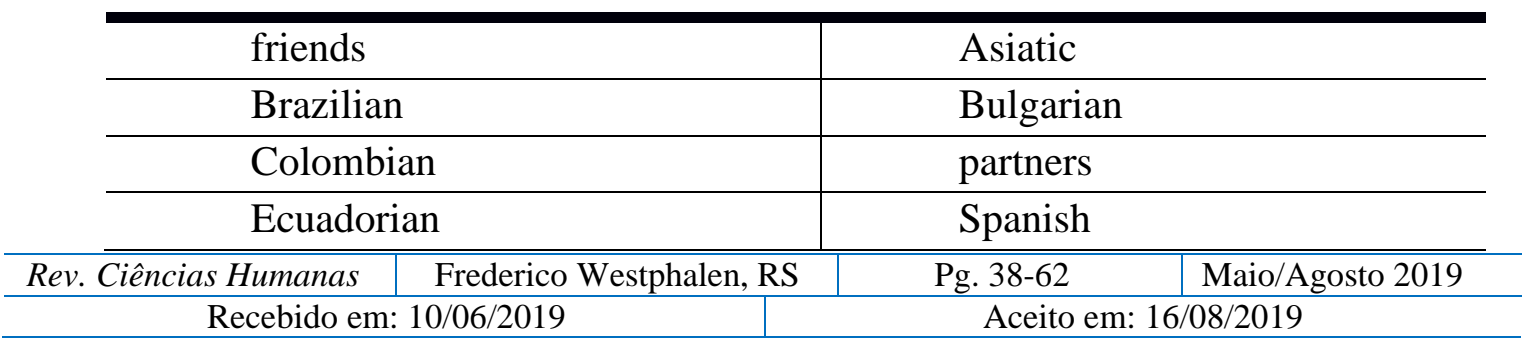




\section{CIÊNCIAS HUMANAS}

REVISTA DO PROGRAMA DE PÓS-GRADUAĞ̈O EM EDUCAĞ̄o

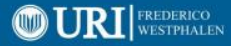

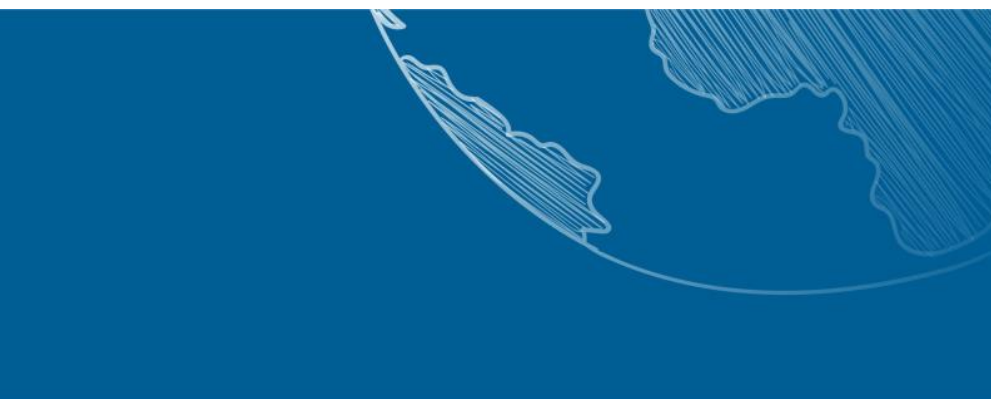

\begin{tabular}{l|l}
\hline ethnic & foreigner \\
\hline family & gipsy \\
\hline ghettoization & ghetto \\
\hline Hispanic & humanity \\
\hline individuals & immigrants \\
\hline institutions & Latin \\
\hline Moroccan & Mexican \\
\hline Moors & nationality \\
\hline personification & people \\
\hline Portuguese & refugees \\
\hline Romanian & Sub-Saharan \\
\hline Venezuelan & Chinese \\
\hline
\end{tabular}

Source: Own elaboration

\section{c) Terms which interlink intercultural processes}

Objective: Classifying and selecting the words contained in the envelope, and negotiating their exchange with other groups for words related to intercultural processes. Their aim is to explain the word corresponding to the group.

Procedure: The group that has got the envelope or box about interculturality processes, will classify these processes so they can produce a speech to explain the given term. The members of this group can ask for other words they may need for their own explanation. To this end, they will negotiate words with the rest of the groups. Finally, the group explains their word thanks to their own terms and the terms that have been taken from other groups.

Materials: Words concerning intercultural or migration processes, according to the table. This list can be increased with everyone's participation.

TABLE 2 - Terms that relate intercultural processes

\begin{tabular}{l|l}
\hline activities & inside \\
\hline outside & Everything changes \\
\hline change & contemporaneous \\
\hline context & strategies \\
\hline global & impact \\
\hline What the heart expresses & movement \\
\hline
\end{tabular}




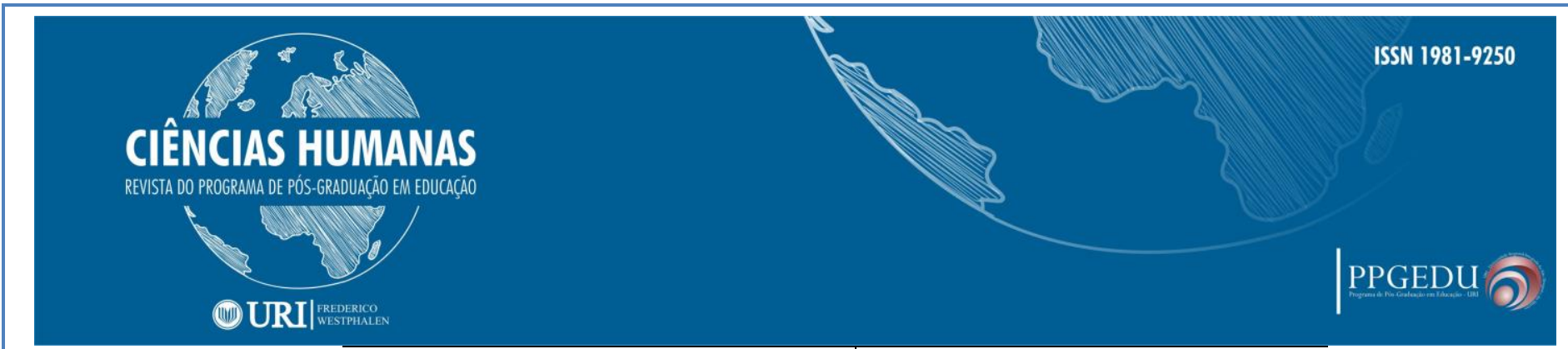

\begin{tabular}{l|l}
\hline It does not repeat & organisms \\
\hline paradigm & plans \\
\hline process & programs \\
\hline protocols & projects \\
\hline regularisation & It is heard \\
\hline It is seen & It is felt \\
\hline segregation & It disrupts it all
\end{tabular}

Source: Own elaboration

\section{d) Terms that link education to interculturality}

The objective and procedure that have been previously seen are similar to the ones for the words on education given to the group. Below, one can see some of them. Of course, they can always be completed.

Result: Once such procedure has been finished, the group, employing a member who has been chosen by the partners and can be named "educator", will describe their selection of terms explaining their given word. As stated, this word has been randomly taken from: interculturality, immigration, challenges, impacts, education and rights. For the explanation of these terms, the participants will have taken from other groups, thanks to negotiation, words referring to "people", "processes", "education", "positive" (+), "negative” (-).

For example: the explanation of the term "migration" will require some words from the group of "people", some others from the "processes" group, terms concerning education, and also positive "in favour" words or, on the contrary, negative ones. The discourse formed thanks to these words will be set on the table or on the floor.

TABLE 3 - Terms that relate education to interculturality

\begin{tabular}{l|l}
\hline art & attention \\
\hline catering for diversity & specific classrooms \\
\hline self-fulfilment & partners \\
\hline compensatory & competition \\
\hline
\end{tabular}




\section{CIÊNCIAS HUMANAS}

REVISTA DO PROGRAMA DE PÓS-GRADUAĞ̈O EM EDUCAĢ̄o

\section{(1)URI|}

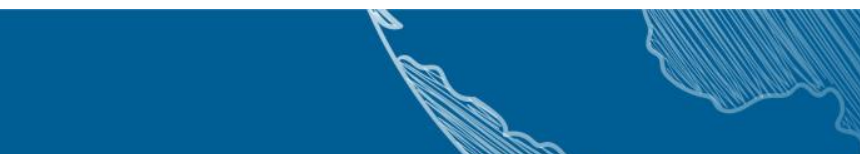

\begin{tabular}{l|l}
\hline comprehension & communication \\
\hline context & coexistence \\
\hline creativity & beliefs \\
\hline culture & curricular \\
\hline homework & deconstruction \\
\hline dedication & dilemmas \\
\hline dynamic & diversification \\
\hline documents & education \\
\hline empathy & meeting \\
\hline understanding & spaces \\
\hline aesthetics & experiences \\
\hline formation & strengths \\
\hline genre & guide \\
\hline equality & social image \\
\hline innovation & integration \\
\hline mediation & minors \\
\hline message & educative model \\
\hline participation & race \\
\hline appreciation & religions \\
\hline services & meaning \\
\hline educative system & solidarity \\
\hline instructional time & mainstreaming \\
\hline vocabulary & vulnerable \\
\hline
\end{tabular}

Source: Own elaboration

e) Positive terms or "in favour", and negative terms or "against" interculturality

Objective: Selecting the words in favour or against interculturality and immigration in order to exchange them for others from the rest of the groups, and to represent the explanation of the intercultural vocabulary that belonged to each group.

Procedure: On the one hand, there is an envelope that contains positive terms which are connected to the area of interculturality and immigration, such as attitudes, comprehension, receptiveness, justice, etc. On the other hand, there is another envelope containing words like deportation, segregation, racism, xenophobia, and some other terms against interculturality. As previously, each group can negotiate the exchange of words to take 


\section{CIÊNCIAS HUMANAS}

REVISTA DO PROGRAMA DE PÓS-GRADUAGĀO EM EDUCACĀOO

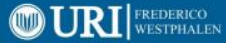

positive or negative ones that can be useful to explain the term they were given at the beginning of this intercultural gamification.

Materials: Two envelopes or boxes. One of them contains words in favour of interculturality, while the other contains the words against it.

TABLE 4 - Positive terms in favour of interculturality

\begin{tabular}{|c|c|}
\hline attitudes & affectivity \\
\hline joy & receptiveness \\
\hline harmony & art \\
\hline attention & self-fulfilment \\
\hline beauty & welcome \\
\hline good new & warmth \\
\hline charisma & closeness \\
\hline citizenship & comprehension \\
\hline committed & communication \\
\hline cohabitation & creativity \\
\hline meaningful & deconstruction \\
\hline commitment & rights \\
\hline challenges & development \\
\hline eye-catching & dialogue \\
\hline willingness & willing \\
\hline empathy & meeting \\
\hline understanding & aesthetic \\
\hline strengths & gratitude \\
\hline equality & integration \\
\hline interest & justice \\
\hline message & It is not just another value \\
\hline not just another & objectivity \\
\hline participation & peace \\
\hline small details & pluralism \\
\hline power & relation \\
\hline break down preconceptions & to know \\
\hline services & always clever \\
\hline significance & solidarity \\
\hline time & tolerance \\
\hline cultural treatment & vulnerable \\
\hline
\end{tabular}

Source: Own elaboration 


\section{CIÊNCIAS HUMANAS}

REVISTA DO PROGRAMA DE PÓS-GRADUAĞ̈O EM EDUCAĞ̄o

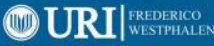

For example, and according to the image, we could claim that for the explanation of the term interculturality, which could have belonged to one of the groups, they selected several words from different envelopes. From the envelope people, the participants chose the words: people, immigrants and refugees; from the envelope processes that belonged to a different group, they took terms such as context and plans. Likewise, from the different options of words that were inside the envelope education, they preferred: culture, understanding and training. Finally, among the terms in favour, the chosen ones were: attitudes, meaningful, equality, integration, solidarity and interrelation, and from the against words, they chose intolerance, discrimination and poverty.

At the end, the group explained and presented to the others that interculturality is the communication and interrelation process among people, whether they are immigrants, refugees or not, from different contexts and cultures. They added that the purpose of such process is the attempt of these people to understand each other, to be mutually integrated in society, with a planned education, making sense of attitudes like equality and solidarity. Furthermore, the group stated that the idea of this is to overcome intolerance, discrimination and poverty.

TABLE 5 - Negative terms that are against interculturality

\begin{tabular}{l|l}
\hline abuse & abuse \\
\hline outside & disruption \\
\hline conflict & crime \\
\hline inequality & discrimination \\
\hline pull effect & deceit \\
\hline enrichment & stereotype \\
\hline exclusion & exploitation \\
\hline deportation & overcrowding \\
\hline illegality & underestimate \\
\hline insecurity & intimidation \\
\hline intolerance & mistreat \\
\hline exclusion & death \\
\hline unattractive & poverty \\
\hline controversy & racism \\
\hline refusal & refugees \\
\hline segregation & without social rights \\
\hline
\end{tabular}




\section{CIÊNCIAS HUMANAS}

REVISTA DO PROGRAMA DE PÓS-GRADUAĞ̈O EM EDUCAĞ̄o

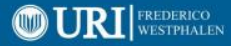

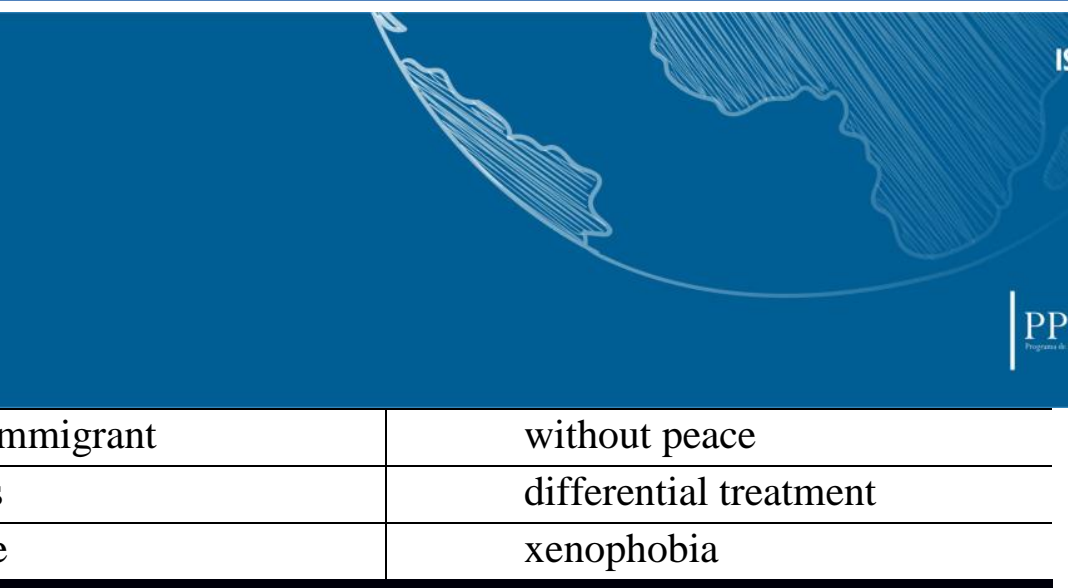

Source: Own elaboration

\section{Gamification 2: "Comparing interculturality to"}

Each group rescues or looks for a word inside an envelope or box, following the given clues until getting it. Later on, they will compare that term to the word interculturality. The gamification dynamic that this comparative procedure follows, helps to synthesise one of the discussed topics, interculturality in this case.

In order to emphasize the important aspects known by the group about interculturality, taking into account the significant experience that the group has, interculturality is compared to other terms and expressions. Then, someone has to indicate the similarities and differences among both terms, their good aspects, the positive ones, their criteria and characteristics, etc.

For instance, if a group finds the term business inside one of the envelopes, they are meant to compare "interculturality to business". Likewise, if a different group finds a sign in which vintage or retro appear written, after reflecting on it, they must compare "interculturality to vintage or retro", highlighting their similarities and differences, their definition, extracting conclusions, etc. These aspects, whether they match or differentiate both terms, can be synthesised in a list, or using a mind map, or a visual thinking, among others.

TABLE 6 - Comparing interculturality to

\begin{tabular}{l|l}
\hline in/out & with/without \\
\hline academic & travel agency \\
\hline occupational agency & yellow journalism \\
\hline black Friday & bureaucratic \\
\hline business & cool fashion \\
\hline passionate & rational \\
\hline supporters & sporty \\
\hline educational & ethnical/folkloric \\
\hline fake news & Halloween \\
\hline wireless/online & low cost
\end{tabular}




\section{CIÊNCIAS HUMANAS}

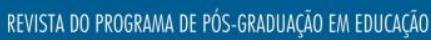

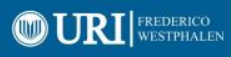

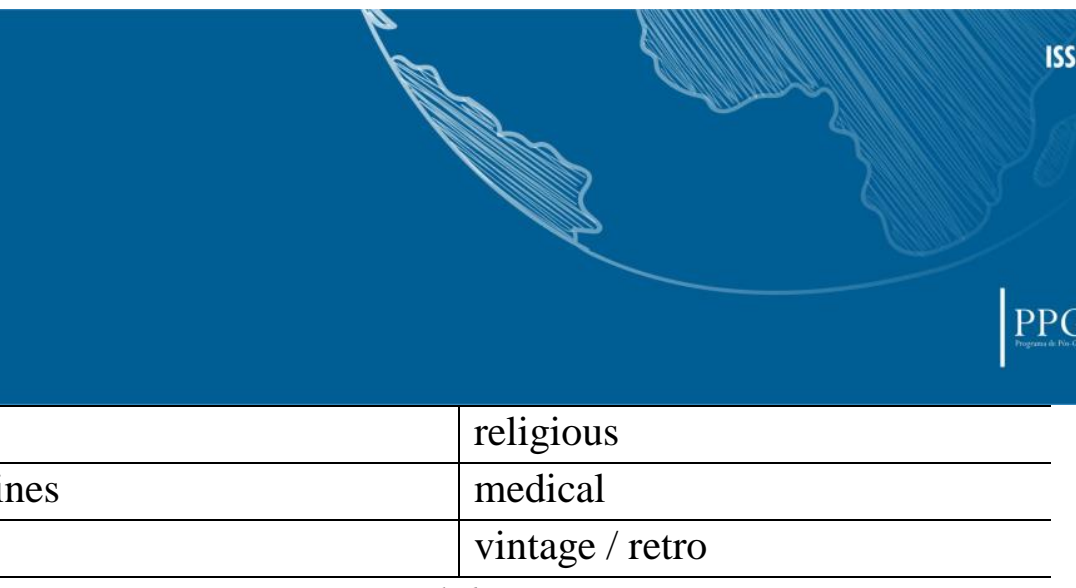

Source: Own elaboration

\section{Gamification 3: "Unboxing Intercultural"}

Unboxing is the experience of discovering a surprise when opening an envelope, unpacking a parcel, or unwrapping something. If the inside contains undiscovered elements that cause surprise since they are novelty and unknown, being in this case our reference topic the interculturality, this can produce rewarding experiences, whether individually or in group. Furthermore, it offers the strategy of being recorded while it is being opened, in order to share the experience and adroitness, especially appealing and tempting among the youngest ones (HERAS; GUERRERO; ESPINOSA, 2018). The unboxing can be shared on social networks, for instance with the \#UnboxingIntercultural. It is important to prepare the recording device, and to have our voice and at least our hands available to tell what we see falling from the box or envelope's inside.

In the envelope or box, two elements related to "the interculturality that provides" and "the interculturality we like" will be placed and later on discovered. By doing this, we pretend to boost the ability to be surprised and to discover new elements, as well as the ability to recognise interculturality to explain and share them,

\section{a) "Interculturality provides...":}

Elements like the ones that appear in the table below are related to "the Interculturality that provides"

TABLE 7 - Interculturality provides

\begin{tabular}{l|l}
\hline Your inner artist & Good humour \\
\hline Good cheer & Commitment \\
\hline Rights' awareness & Entertainment \\
\hline Feedback & Interest \\
\hline The best of the deals & The mindfulness \\
\hline Mystery & The movement \\
\hline My life's meaning & Being always ready \\
\hline Joy & Beauty \\
\hline
\end{tabular}




\section{CIÊNCIAS HUMANAS}

REVISTA DO PROGRAMA DE PÓS-GRADUAGĀO EM EDUCACĀOO

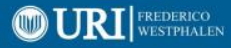

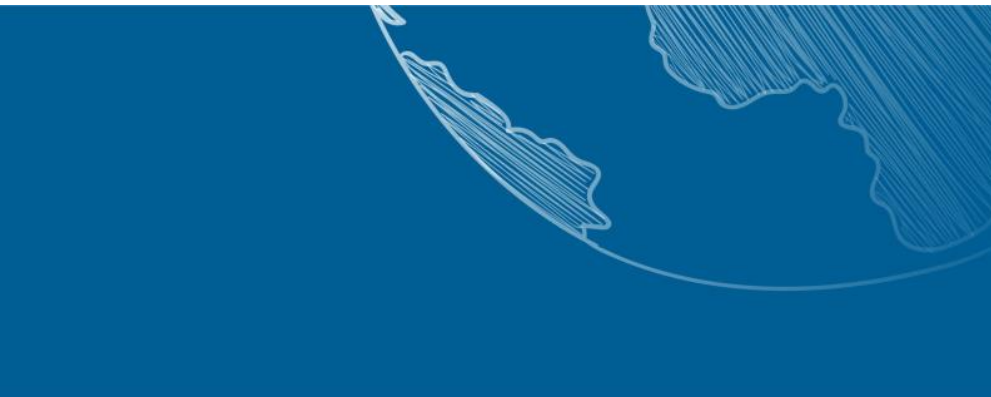

\begin{tabular}{l|l}
\hline Positive willingness & Cooperation \\
\hline Communication & Cooperation \\
\hline Creativity & Creativity \\
\hline Curiosity & Empathy \\
\hline Gamification & Gratitude \\
\hline Equality & Imagination \\
\hline Integration & Justice \\
\hline Observation & Patience \\
\hline Peace & Solidarity with everyone \\
\hline (strong) Emotions & Challenges \\
\hline Challenges & The small details \\
\hline My receptiveness & My art \\
\hline My attention & Our affectiveness \\
\hline Our proximity & Our tolerance \\
\hline Our attitudes & Our strengths \\
\hline Your body and soul & Your expressiveness \\
\hline Your musicality & Your dreams \\
\hline
\end{tabular}

Source: Own elaboration based on

www.edelvives.com/es/info/unboxingEdelvives

For the unboxing, these elements may be included, as well as others that we design. Once it is opened, it will be possible to work with the found terms in groups: Ordering, classifying, explaining and sharing them through different means. This is a surprise experience.

\section{b) "The interculturality we like":}

At "the interculturality we like", we will find other specific aspects that add innovation, such as:

TABLE 8 - Thanks to interculturality we like

\begin{tabular}{l|l}
\hline Learning with friends & Daring to do everything \\
\hline Dancing and jumping & Singing very loudly \\
\hline Telling stories and tales & Disguising ourselves \\
\hline Art & Listening to our breathing \\
\hline Shouting for joy & Drawing \\
\hline
\end{tabular}




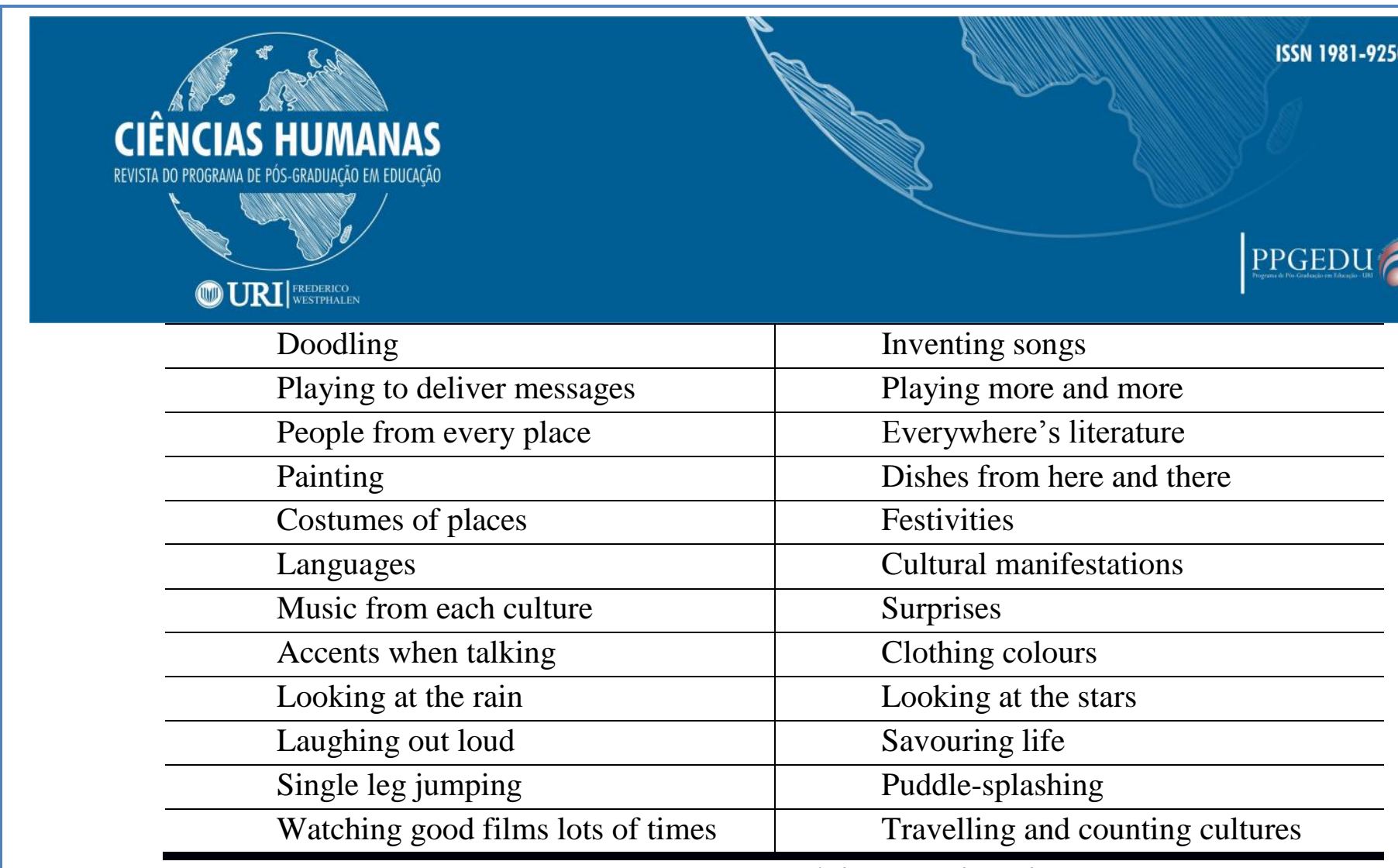

Source: Own elaboration based on

www.edelvives.com/es/info/unboxingEdelvives

These signs, written on paper sheets or cardboard, that fall from inside the envelope, can be interrelated in group. It is also possible for the group to express freely what the terms suggest them in relation to interculturality and its development. A competition with all the videos or photos that have been shared on social networks can be promoted, always respecting the protection, intimacy and security criteria.

\section{CONCLUSIONS}

Interculturality as a principle, attitude and value, has a progressive significance during the last decades. As a result of a constant incompatibility of different vital interests, beliefs, communication, needs and approaches, there are cultural conflicts among different peoples wielding violence and confrontation. Consequently, the more cultural conflicts there are, the more evident and necessary interculturality results. Hence, the transition from the multicultural to the intercultural was marked by a society evolution when sharing common life projects. This required Intercultural Education to be present in society and at school, in order to enforce its values framework through specific intercultural models. 


\section{CIÊNCIAS HUMANAS}

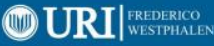

Formative workshops with their theoretical-practical component have been always demanded from both formal and no formal education. Nowadays, they are recovering with a visible and enabling detail, which is suitable for all social, medical, cultural, educative, and working contexts, among others.

The emergence of gamification as a motivational element in a task with clear objectives, has produced its incorporation also to the educational area. Therefore, it has resized education through the participative or individual game that follows certain accepted rules, using its own techniques with the purpose of achieving the expected learning.

The connection between the teaching and the practical learning of these workshops, together with the playful characteristic of gamification, has developed an Intercultural Education based on the improvement of several aspects: Communication, respect, tolerance, inclusion, equality, harmony and integral education towards all societies, aiming to their training and catering for cultural diversity. Thanks to this, the three elements (learning, teaching and gamification) add a concrete and specific bonus characterised for being technical, formative and playful.

The incorporation of gamification to education requires the knowledge, implementation and assessment of all the experiences carried out. Thus, the remarkable elements of a gamificated education have to go through several steps: the establishment of the game rules, the mechanics of rewards and incentives, the clarification of the goal, the connection of the fluid's level, the players and their motivation, and the problem-solving.

The preparation of the Intercultural Education workshop or of the gamified experience has some requirements: Clear objectives, being aware of the characteristics of the addressee group, the creation of a story about the topic and context, the setting of the rules, the preparation of the resources, boxes, envelopes, and other material, the organisation of the challenges and enigmas, the final reflection, and the assessment of what has happened.

There is a contribution of Neuroeducation through Neuroscience, Psychology and Education, as the three sciences that stimulate the educational learning. Therefore, there are also contributions of Intercultural Education and gamification, since brain functions are developed through the educational technologies and strategies. These ones foster factors such as climate, physical environment and emotional learning. For this, the best methodologies are 


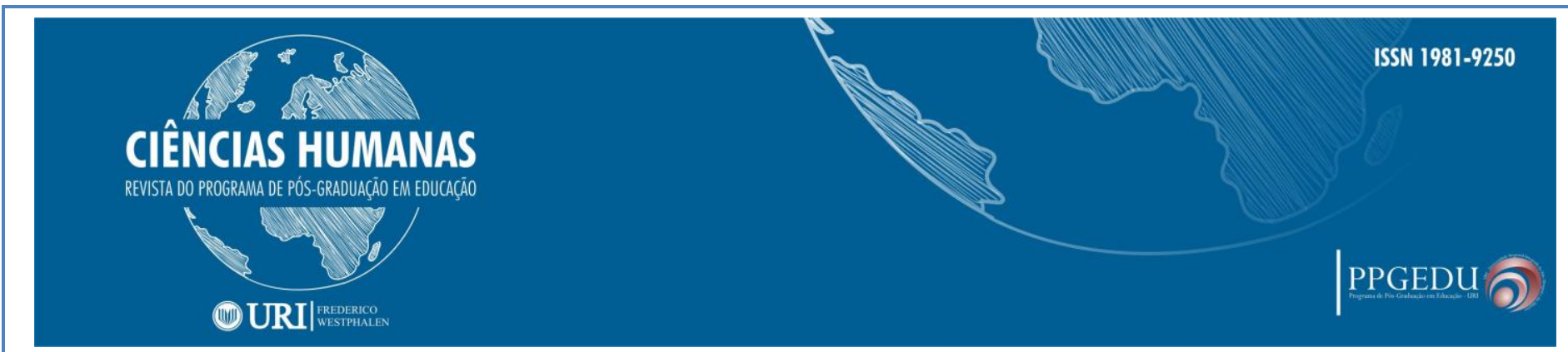

put into practice, as well as different teaching and learning styles and materials that vary in forms, techniques and activities, and in which it is possible to promote significant learning and feedback.

The work experienced at the gamification and Intercultural Education workshop relies on a remarkable teamwork characterised by the active participation, cooperation and collaboration among all. This is essential for both teaching and learning from the new neuroeducative perspective.

\section{REFERENCES}

BEACCO, J. C., BYRAM, M., CAVALLI, M., COSTE, D., CUENAT, M. E., GOULLIER, F., \& PANTHIER, J. Guide for the development and implementation of curricula for plurilingual and intercultural education. Council of Europe: 2016.

BUENDIA EISMAN, L., EXPOSITO LÓPEZ, J., AGUADEZ RAMÍREZ, E. M., \& SÁNCHEZ NÚÑEZ, C. A. Análisis de la convivencia escolar en las aulas multiculturales de Educación Secundaria. Revista de Investigación Educativa, Granada, Espanha, v. 33, n.2, p.303-319, 2015.

CLARK, J. S. B.; DERVIN, F. (Orgs.). Reflexivity in language and intercultural education: rethinking multilingualism and interculturality. Abingdon, Inglaterra: Routledge. 2014.

DERVIN, F. Towards post-intercultural teacher education: analysing 'extreme' intercultural dialogue to reconstruct interculturality. European Journal of Teacher Education, v.38, n.1, p. 71-86, 2015.

DÍAZ-CRUZADO, J Y TROYANO, Y. El potencial de la gamificación aplicado al ámbito educativo. III Jornadas de Innovación Docente. Innovación Educativa: respuesta en tiempos de incertidumbre. Sevilla: Universidad de Sevilla. Facultad de Ciencias de la Educación. 2013. Recuperado de https://idus.us.es/xmlui/handle/11441/59067?show=full

DICHEVA, D., DICHEV, C., AGRE, G., \& ANGELOVA, G. (2015). Gamification in education: a systematic mapping study. Educational Technology \& Society, v.18, n.3, p.75$88,2015$.

EDELVIVES. Jornadas Educativas. Dale al coco. 2019 Disponible en https://www.edelvives.com/es/jornadas-educativas

EDELVIVES. Jornadas Educativas. Taller de Brain Less Escape. 2019. Disponible en https://www.edelvives.com/es/Noticias/d/taller-1-brainlessescape 


\section{CIÊNCIAS HUMANAS}

REVISTA DO PROGRAMA DE PÓS-GRADUAĞ̈O EM EDUCAĢĀO

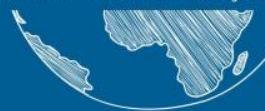

(10)URI| |rRDERco

GONZÁLEZ GONZÁLEZ, C. S., \& MORA CARREÑO, A. Técnicas de gamificación aplicadas en la docencia de Ingeniería Informática. ReVisión, v.8, n.1, 2015.

GONZÁLEZ-ALONSO, F. Y DE CASTRO-HERNÁNDEZ, R.M. (2012). Interculturalidad y Valores en el currículo intercultural. Papeles Salamantinos de Educación. n. 16, 2012, p. 189-212.

GONZÁLEZ-ALONSO, F. Y DE CASTRO-HERNÁNDEZ, R.M. Mejorar la convivencia. Educación en valores y Derecho Educativo. Valencia: Tirant lo Blanch, 2019.

HEW, K. F., HUANG, B., CHU, K. W. S., \& CHIU, D. K. Engaging Asian students through game mechanics: Findings from two experiment studies. Computers \& Education, v.92, 2016, p.221-236.

HORIZON REPORT. Higher Education Edition. 2013. Disponible en https://www.nmc.org/system/files/pubs/1359993875/2013-horizon-report-HE.pdf

HUANG, B., \& HEW, K. F. Implementing a theory-driven gamification model in higher education flipped courses: Effects on out-of-class activity completion and quality of artifacts. Computers \& Education, v.125, 2018, p. 254-272.

KAPP, K. The gamification of learning and instruction: game-based methods and strategies for training and education. San Francisco: John Wiley \& Sons, 2012.

LEEMAN, Y., \& LEDOUX, G. Teachers on intercultural education. Teachers and Teaching: theory and practice, v.11, n.6, 2005, p. 575-589.

LEIVA OLIVENCIA, J. J. La educación intercultural en una encrucijada de caminos: reflexiones pedagógicas para la construcción de una escuela intercultural. Espiral Cuadernos del Profesorado. v.4, n.7, 2011.

MAHUTA, D. Building virtual language communities through social media - Because we don't live the village life anymore. In.: WHAANGA, H.; Keegan T.; APPERLEY, M. (Eds.). He Whare Hangarau Māori - Language, culture \& technology. Hamilton, New Zealand: Te Pua Wānanga ki te Ao, 2017, p.42-45. Retrieved from https://www.waikato.ac.nz/fmis/research-practice/te-reo-hub/he-whare-hangarau-maori

MOORE, L., \& CAMPBELL, N. Novel interprofessional learning for healthcare students: an escape room pilot. Focus on Health Professional Education: a Multi-Professional Journal, v. 20, n.1, 2019, p.1-7.

MOWLABOCUS, S. 'Let's get this thing open': the pleasures of unboxing videos. European Journal of Cultural Studies, 2018.

NACKE, L. E., \& DETERDING, C. S. The maturing of gamification research. Computers in Human Behaviour, 2017, p.450-454.

NICHOLSON, S. A recipe for meaningful gamification. In.: EINERES, T.; WOOD, L. Gamification in education and business. Springer: Cham, 2015. p. 1-20.

\begin{tabular}{c|c|c|c}
\hline Rev. Ciências Humanas & Frederico Westphalen, RS & Pg. 38-62 & Maio/Agosto 2019 \\
\hline \multicolumn{2}{c|}{ Recebido em: 10/06/2019 } & Aceito em: 16/08/2019 \\
\hline
\end{tabular}




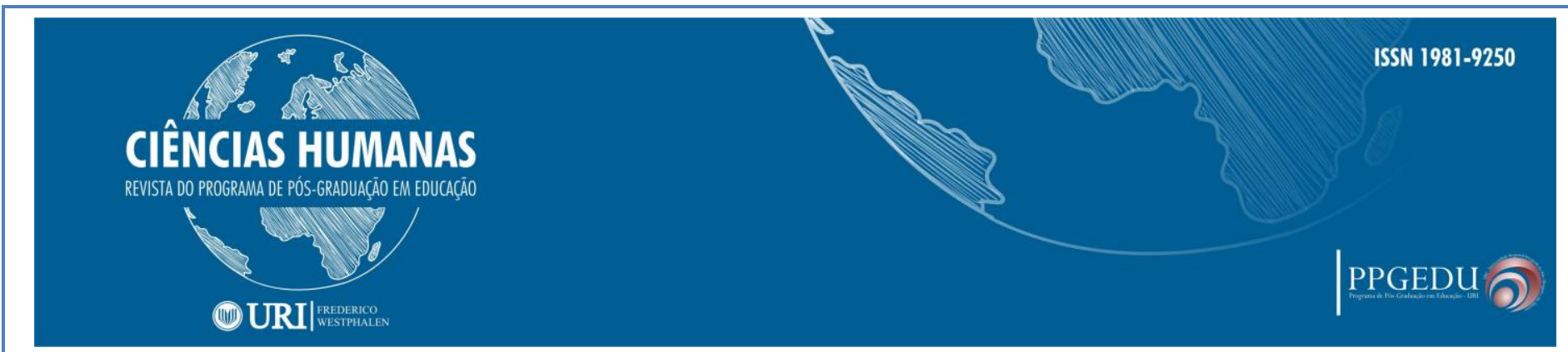

NICHOLSON, S. Peeking behind the locked door: a survey of escape room facilities. 2015. White Paper available online at http://scottnicholson. com/pubs/erfacwhite. pdf.

PÉREZ-LÓPEZ, I., \& RIVERA-GARCÍA, E. Formar docentes, formar personas: análisis de los aprendizajes logrados por estudiantes universitarios desde una experiencia de gamificación. Signo y Pensamiento, v.36, n.70, 2017, p. 112-129.

PUIG I MORENO, G. Hacia una pedagogía intercultural. Cuadernos de Pedagogía, n. 196, 1991, p. 12-16.

RODRÍGUEZ NAVARRO, H., GALLEGO LÓPEZ, B., SANSÓ GALIAY, C., NAVARRO SIERRA, J. L., VELICIAS SÁNCHEZ, M., \& LAGO SALCEDO, M. La educación intercultural en los centros escolares españoles. Revista Electrónica Interuniversitaria de Formación del Profesorado, v.14, n.1, 2011, p.101-112.

SEGURA, S. G. De la educación indígena a la educación bilingüe intercultural. Revista Mexicana de Investigación Educativa, v.9, n.20, 2004, p. 61.

URH, M., VUKOVIC, G., \& JEREB, E. (2015). The model for introduction of gamification into e-learning in higher education. Procedia-Social and Behavioral Sciences, v.197, 2015, p.388-397.

WIEMKER, M., ELUMIR, E., \& CLARE, A. Escape room games. Game Based Learning, v.55, 2015.

WIGGINS, B. E. An overview and study on the use of games, simulations, and gamification in higher education. International Journal of Game-Based Learning (IJGBL), v.6, n.1, 2016, p.18-29.

ZICHERMANN, G. Y CUNNINGHAM, C. Gamification by design: implementing game mechanics in web and mobile apps. Cambridge, MA: O'Reilly Media, 2011. 